\title{
Targeting Some Enzymes with Repurposing Approved Pharmaceutical Drugs for Expeditious Antiviral Approaches Against Newer Strains of COVID-19
}

\author{
Swati Sucharita Mohanty, ${ }^{1}$ (]) Chita Ranjan Sahoo, ${ }^{2}$ (1) and Rabindra Nath Padhy ${ }^{2,3}$ (I)
}

Received 1 May 2021; accepted 29 June 2021

\begin{abstract}
At present, global vaccination for the SARS-CoV2 virus 2019 (COVID-19) is $95 \%$ effective. Generally, viral infections are arduous to cure due to the mutating nature of viral genomes, with the consequent quick development of resistance, posing significant fatalities or hazards. The novel corona viral strains are increasingly lethal than earlier variants, as those evolve faster than imagined. Despite the emergence of several present innovative treatment options, the vaccines, and available drugs, the latter still are the needs of the time. Therefore, repurposing the approved pharmaceutical drugs of a well-known safety profile would be ascertained to provide faster antiviral approaches for the newer strains of COVID-19. Recently, a combination of remdesivir, which has a competitively inhibitory effect on the nucleotide uptake in the virus, and the merimepodibs, an inhibitor of the enzyme inosine monophosphate dehydrogenase, which has a role in the synthesis of nucleotides of guanine bases, is in use in phase 2 clinical trials. However, new investigations suggest that using remdesivir, there is no statistically significant difference with uncertain clinical importance for moderate COVID-19 patients. Herein, an intellectual selection of approved drugs based on the safety profile is described, to target any essential enzymes that are required for the virus-receptor contact, fusion, and/or different stages of the life cycle of this virus, should help to screen drugs against newer strains of COVID-19.
\end{abstract}

KEY WORDS: COVID-19; SARS CoV2; positive-sense single-stranded RNA virus; repurposing drugs; target inhibition.

\section{INTRODUCTION}

The SARS-CoV2 virus 2019 (COVID-19) is a continually rising viral contagion resulting from a newer unfamiliar severe acute respiratory syndrome coronavirus 2, which causes an acute respiratory distress syndrome (ARDS). ARDS may trigger multi-organ failures, blood clots, septic shock, and cytokine storm [1-3]. Ubiquitously, it was primarily recorded in Wuhan, China, amidst an upsurge of respiratory infection cases during December 2019 that resulted in the current pandemic everywhere infecting in 216 countries, buccaneering the stability of humans on earth, initially. The global rolling updates of COVID-19 are that more than 3,539,727 confirmed cases of deaths and more than $170,217,299$ confirmed cases [4, 5]. It is mostly transmitted among individuals from the discharge of the nose and droplets of the saliva of infected persons, when they sneeze

\footnotetext{
${ }^{1}$ Cytogenetics Laboratory, PG Department of Zoology, Utkal University, Bhubaneswar, Odisha 751004, India.

${ }^{2}$ Central Research Laboratory, IMS \& SUM Hospital, Siksha O Anusandhan Deemed to be University, Bhubaneswar, Odisha 751003, India.

${ }^{3}$ To whom correspondence should be addressed. (e-mail: rnpadhy54@gmail.com)
}

or cough or talk. Facemasks have become the totem pole of this era.

There is no dependable cure and suitable therapeutics for COVID-19; only the emergency authorization has been in practice with a few approved old antiviral drugs such as remdesivir, a nucleoside analog and which inhibits the RNAdependent RNA polymerase ( $\mathrm{RdRp}$ ) in viruses, as administration showed a comparative quick recovery of severe cases $[6,7]$. Vaccines now have a $95 \%$ effectiveness, which means global vaccination is accepting the challenge with a hope to avoid tainting a greater number of lives and will restrict dissemination across communities; but one in twenty persons who get vaccinated may not develop immunity to escape from acquiring the disease [8]. On 21 August 2020, the Journal of the American Medical Association (JAMA) promulgated the clinical efficacy of remdesivir in phase 3 trials, with the standard care for moderate COVID-19 patients. They compared 10 days of treatment with remdesivir to that of placebo-controlled standard care and found out that there is no statistically significant difference with uncertain clinical importance for moderate COVID-19 patients. Remdesivir was indicated to be beneficial in a placebo-controlled trial for severe COVID-19 patients, but in moderate categorized patients, its clinical efficacy is concealed $[9,10]$. 
Indeed, viral infections are arduous to cure due to their mutating genomes; consequently, that poses a significant hazard/fatality to humanity. There is a consistent avalanche of novel mutated viral strains that are resistant, which need to be addressed by newer fresh antiviral agents with lesser side effects and host toxicity. Over the past and recent time, lethal viruses have triggered pandemics worldwide; among those, mutants of COVID-19 have been the ghoulish respiratory viral strains causing human misery. Today, a couple of medicines and vaccines have been formulated to efficaciously handle viral diseases, as viruses tend to mutate fast. However, most of these antiviral medicines have detrimental reactions on man, which in the long-term develop resistances due to mutations [11-13]. RNA viruses are likely to possess superior mutation rates, as a side effect for the preference of accelerated genomic replication [13]. When the world is going through a pandemic predicament, it is crucial that there is no much time available for the essential steps of drug development and testing. Even after global vaccination, the newer viral strains by mutation get resistant - perfecting obeying to Darwin's "survival of the fittest" theory. The recent vaccine(s) with $95 \%$ effectiveness may not stop the world from the new pandemic situations that are similar and different in different countries from the newer avalanche of corona strains. However, the novel use of the approved pharmaceutical drugs could provide expeditious antiviral approaches from newer strains of COVID-19 too.

Inhibition at several stages of the life cycle of this virus could be the advantageous targets for curative treatments. Obviously, viruses have a specific life cycle, depending on the strain, notwithstanding every virus follows a specific paradigm: [1] adhesion on the host cell, [2] liberation of the viral genome within the host cell, [3] replication of viral parts by subjugating host cell machinery, [4] congregation of the viral parts into new virus particles, and [5] liberation of the new virus particles to taint fresh host cells. Similarly, the life cycle of coronavirus involves tethering of its coat proteins to the surface receptors of the host cell, thereby its RNA entering inside the cell, by uncoating out the viral genome followed by replicase protein translation, RNA transcription, RNA synthesis, the congregation of the viral parts, and liberation of the new viruses to begin the cycle again with new host cells (Tables I,II). This review focuses on the fresh use of previously approved antiviral and others drugs to target inhibition of the essential enzymes that are required for virus-receptor contact, fusion, and/or different stages of the life cycle of this virus for expeditious antiviral approaches against newer strains of COVID-19.

\section{THE STRUCTURE AND LIFE CYCLE OF SARS-COV-2}

Structurally coronaviruses are rounded, encased with a positive-sense single-stranded RNA virus (or (+) ssRNA virus). This ssRNA functions as an mRNA and can be directly translated into viral proteins in the host cell. An RNA-dependent RNA polymerase ( $R d R P)$, which is encoded by the virus genome, synthesizes RNA out of the viral RNA template. SARS-CoV-2 is a zoonotic virus that closely resembles $82 \%$ of the severe acute respiratory syndrome coronavirus (SARS-CoV) genome [45]. Each virus particle has a nucleocapsid $(\mathrm{N})$, an enzyme hemagglutinin esterase (HE), envelope (E), membrane (M), and spike (S), as the structural proteins (Fig. 1) [46-48]. Genomic analyses of SARS-CoV-2 have divulged the existence of ten genes encoding for ten diverse proteins which are organized in a precise way in the genome. The initial gene is ORF1ab followed by spike (S) glycoprotein gene, ORF3a gene, envelope (E) gene, membrane (M) gene, ORF6 gene, ORF7a gene, and ORF8 gene, nucleocapsid (N) gene with an alternative open reading frame with an accessory protein ORF9b gene, and ORF10 gene flanked by 5-untranslated region (5-UTR) and 3 untranslated region (3-UTR) [49]. The spike protein gives the virus a crown look, hence the name "corona." Amidst all the recognized RNA viruses, coronaviruses have the longest genome, about 26.4-31.7 kilobase pairs [49]. Owing to the existence of $5^{\prime}$ cap structure, in addition to, the $3^{\prime}$ poly-A tail, the $(+)$ ssRNA performs as the mRNA for protein translation. Nonstructural proteins (nsps) encoded by replicase gene occupy the two-thirds of the viral genome; just the rest one-third encode accessory and structural proteins. The structural arrangement of the SARSCoV-2 genome is 5'-leader-UTR-replicase-S-E-M-N-3'UTRpoly(A) tail, where the accessory genes are scattered inside of the structural genes at the $3^{\prime}$ end $[47,50]$.

Entry into the host cell is interceded by the spike protein, which tethers to the host angiotensin-converting enzyme2 (ACE2) receptor, by the mechanism called host cell recognition. These ACE2 receptors are present in the airway epithelial cells in high concentrations. After complete tethering of spike proteins and host ACE2 receptor, the viral RNA enters the host by either of the two processes. Fusion of viral or host membranes allows the viral RNA to access inside of the host cytoplasm or it is the "endocytosis of the virus," where the receptor envelops the intruding virus by the cell membrane and transports it into the cytoplasm, as a vesicle. Subsequently, after entry, the viral RNA has emancipated inside the through the uncoating of the RNA (Fig. 2). Immediately after the entry into the cytoplasm, the translation of 2 replicase poly-protein (a bulky protein that can be split into lesser protein) ensued from the replicase gene of the RNA strand. Viral proteinases (enzymes that disintegrated protein) thereafter transform the poly-proteins into several single replicase proteins. An unabridged negative-strand RNA is generated with the help of the replicase, which subsequently functions as a template for positive-sense singlestranded virus RNA [48, 50]. Viral assembly by integration of viral enzymes, (+)ssRNA, and nucleoproteins inside the coat with spike proteins is the natural complex process that forms gigantic loads of infective virus particles.

Compared to (+) ssRNA, a negative-strand RNA cannot be translated directly as it is complementary to mRNA. Therefore, RNA polymerase modifies it into a plus-strand RNA first. Shorter mRNAs are transcribed from the unabridged negative-strand RNA, which ciphers for the structural and nonstructural accessory proteins, and the viral proteinases. The transitional area amidst the endoplasmic reticulum (ER) and the Golgi apparatus of the host cell serves as the site for the congregation of freshly generated plus-strand RNAs, structural and nonstructural proteins into membrane-bound vesicles. These vesicles mature and are seen budding from the Golgi apparatus and getting liberated into the extracellular space, ultimately those fusing with the 
Table I. Essential Enzymes as Approved Pharmaceutical Drugs as Target Having Potential Therapeutic Value for COVID-19 Treatment

\begin{tabular}{|c|c|c|c|c|}
\hline Sl. No. & Essential enzyme/proteins as target & Approved pharmaceutical drugs & Initially approved for & References \\
\hline \multicolumn{5}{|c|}{ Inhibitors of host protease } \\
\hline 1 & TMPRSS2 & Camostat mesilate & Oral squamous cell carcinoma, & \multirow[t]{2}{*}{ [14-19] } \\
\hline 2 & Cathepsin B/L & Nafamostat mesilate & $\begin{array}{l}\text { dystrophic epidermolysis, exocrine } \\
\text { pancreatic enzyme inhibition, } \\
\text { chronic pancreatitis, acute } \\
\text { pancreatitis, disseminated } \\
\text { intravascular coagulation and } \\
\text { for anticoagulation in extracorporeal } \\
\text { circulation }\end{array}$ & \\
\hline \multicolumn{5}{|c|}{ Blocking fusion machinery } \\
\hline 1 & Spike protein & Arbidol (umifenovir) & $\begin{array}{l}\text { Broad-spectrum respiratory viruses, } \\
\text { asthma and chronic obstructive } \\
\text { pulmonary disease (COPD) }\end{array}$ & {$[19,20]$} \\
\hline \multicolumn{5}{|c|}{ Inhibitors of Abl kinase } \\
\hline 1 & Abl kinase & $\begin{array}{l}\text { Imatinib mesylate } \\
\text { Saracatinib }\end{array}$ & $\begin{array}{l}\text { Cancer } \\
\text { Tuberous sclerosis complex (TSC) }\end{array}$ & {$[7,21]$} \\
\hline \multicolumn{5}{|c|}{ Inhibitors of ACE2 } \\
\hline 1 & ACE2 & $\begin{array}{l}\text { Mefloquine hydrochloride } \\
\text { Selamectin } \\
\text { Cepharanthine }\end{array}$ & $\begin{array}{l}\text { Malaria } \\
\text { Helminth and parasitic infection } \\
\text { Inflammatory }\end{array}$ & {$[14]$} \\
\hline \multicolumn{5}{|c|}{ Regulators of endosomal $\mathrm{pH}$} \\
\hline 1 & Endosomal pH & $\begin{array}{l}\text { Chloroquine } \\
\text { Hydroxychloroquine }\end{array}$ & $\begin{array}{l}\text { Malaria } \\
\text { Autoimmune diseases } \\
\text { Q fever }\end{array}$ & {$[14,22]$} \\
\hline \multicolumn{5}{|c|}{ Inhibitors of viral protease } \\
\hline 1 & Papain-like protease (PLpro) & $\begin{array}{l}\text { Telaprevir, velpatasvir, } \\
\text { grazoprevir, paritaprevir, } \\
\text { simeprevir, asunaprevir } \\
\text { boceprevir }\end{array}$ & Hepatitis $\mathrm{C}$ virus & [23-27] \\
\hline \multirow[t]{2}{*}{2} & \multirow[t]{2}{*}{$\begin{array}{l}\text { Main protease (Mpro)/ } \\
\text { 3C-like protease (3Clpro) }\end{array}$} & $\begin{array}{l}\text { Nelfinavir mesylate } \\
\text { Saquinavir mesylate }\end{array}$ & HIV & [28-30] \\
\hline & & Oseltamivir & Influenza & {$[31-34]$} \\
\hline \multicolumn{5}{|c|}{ Inhibitors of oxysterol-binding protein } \\
\hline 1 & Oxysterol-binding protein (OSBP) & Itraconazole (ICZ) & Fungal lung infection & [35-39] \\
\hline \multicolumn{5}{|c|}{ Blockers of viral polymerase } \\
\hline 1 & $\begin{array}{l}\text { RNA-dependent RNA } \\
\text { polymerase (RdRP) }\end{array}$ & $\begin{array}{l}\text { Favipiravir, remdesivir, } \\
\text { ganciclovir/valganciclovir, } \\
\text { entecavir, stavudine, } \\
\text { abacavir, cidofovir, } \\
\text { tenofovir, galidesivir, } \\
\text { sofosbuvir, and ribavirin }\end{array}$ & Ebola virus & {$[7-9,14,16,17,40]$} \\
\hline \multicolumn{5}{|c|}{ Intracellular redox homeostasis } \\
\hline 1 & $\begin{array}{l}\text { Redox enzymes such } \\
\text { as thioredoxin reductase }\end{array}$ & Auranofin & Rheumatoid arthritis & [16-19] \\
\hline \multicolumn{5}{|c|}{ Immunomodulator } \\
\hline 1 & Immune remodeling & Thalidomide & H1N1 influenza & {$[41-43]$} \\
\hline & & Anakinra & Rheumatoid arthritis & {$[42,44]$} \\
\hline
\end{tabular}

host cell membrane. The liberation of new SARS-CoV-2 particles does not bust the host cell, and the process is called non-lytic exocytosis [47, 50-52] (Fig. 2).

\section{TARGETING VIRUS-HOST FUSION}

\section{Inhibitors of Host Protease}

SARS-CoV-2 spike protein is activated by tethering to the host angiotensin-converting enzyme 2 (ACE2) receptors which are found in the airway epithelial cells in high concentrations. Consequently, it needs serine protease transmembrane serine protease-2 (TMPRSS2) and cysteine proteases cathepsin L/B (CTSL/CTSB), for making two independent entry passageways approachable (endocytosis and fusion) [53-56]. Thus, targeting simultaneously TMPRSS2 and cathepsin B/L may prevent virus entry (Fig. $3)$. This could be achieved by the repurposing of the presently approved drugs. Camostat mesilate and nafamostat mesilate are the inhibitors of TMPRSS2, which have been shown in vivo to impede the entrance of SARS-CoV-2 into host lung cells and MERS-CoV, respectively [14, 57]. 
Table II. Repurposing Some Drugs Against COVID-19 Treatment<smiles>[H][Y]N[C@H]1CC(C(=O)OCC)=C[C@H](OC(CC)CC)[C@H]1NC(C)=O</smiles><smiles>CN(C)C(=O)COC(=O)Cc1ccc(OC(=O)c2ccc(N=C(N)N)cc2)cc1</smiles><smiles>CCC(CC)COC(=O)[C@H](C)N[P+](=O)(OC[C@H]1O[C@@](C#N)(c2ccc3c(NN)ncnn23)[C@H](O)[C@@H]1O)Oc1ccccc1</smiles><smiles>N=C(N)c1ccc2cc(OC(=O)c3ccc(N=C(N)N)cc3)ccc2c1</smiles><smiles>CSC[C@@H](CN1C[C@@H]2CCCC[C@H]2C[C@H]1C(=O)NC(C)(C)C)[C@H](NC(=O)c1cccc(O)c1C)[C@H](O)CSc1ccccc1</smiles> 

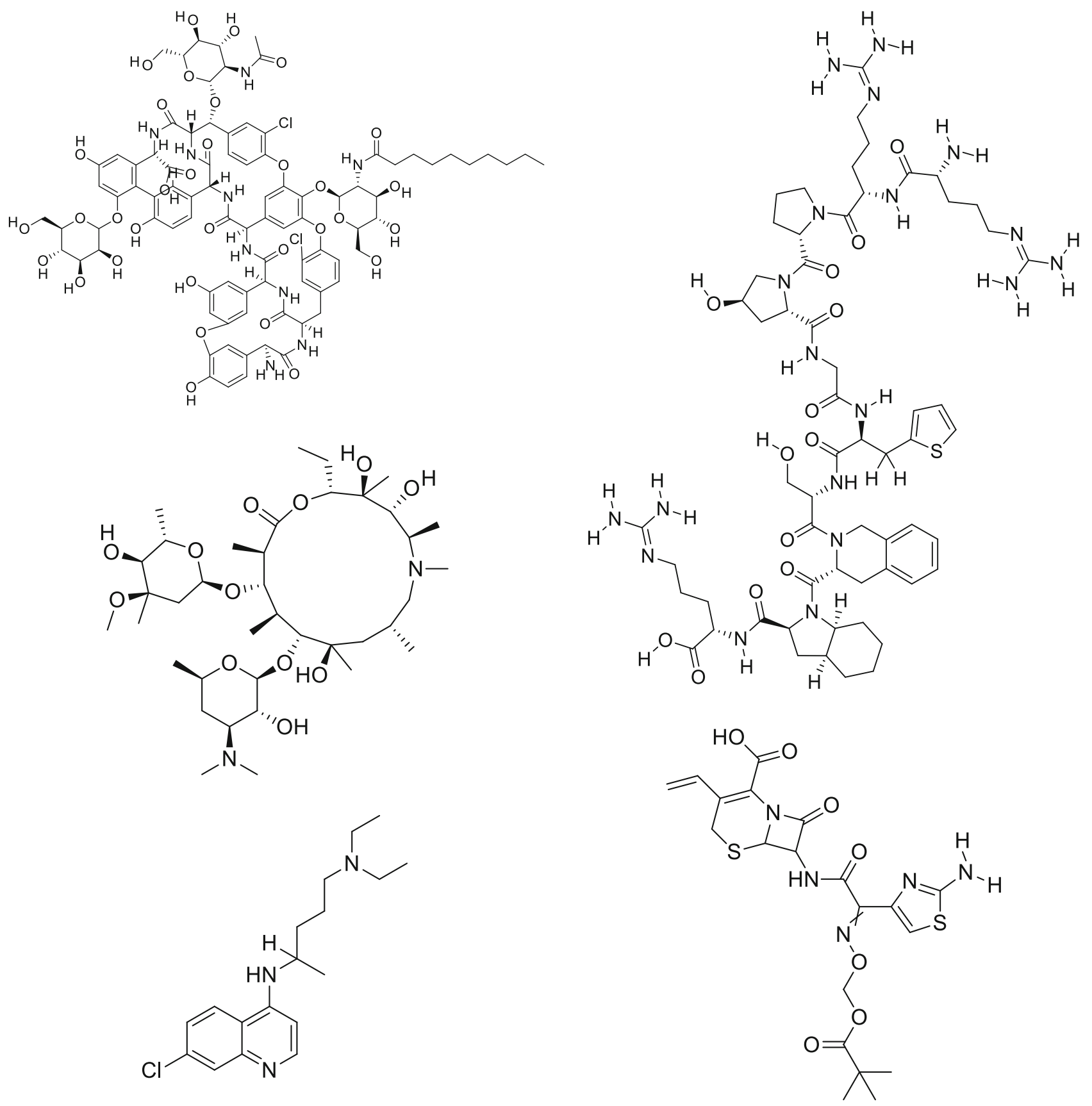<smiles>CCN(CCO)CCCC(C)Nc1ccnc2cc(Cl)ccc12</smiles><smiles>O=C1CCC(N2C(=O)c3ccccc3C2=O)C(=O)N1</smiles> 


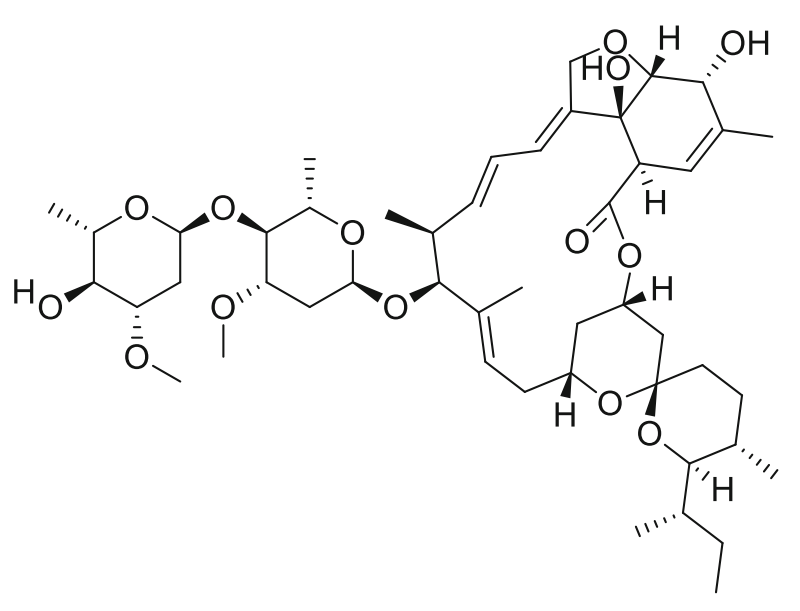<smiles>CC(=O)Oc1ccccc1C(=O)Nc1ncc([N+](=O)[O-])s1</smiles><smiles>CC[C@H]1CN2CCc3cc(OC)c(OC)cc3[C@H]2C[C@H]1C[C@H]1NCCc2cc(OC)c(OC)cc21</smiles><smiles></smiles>

\section{Blocking Fusion Machinery}

The broad-spectrum drug such as Arbidol inhibits the entrance of the virus into the host cell. It is an indole-derivative that acts towards a broad array of nonenveloped and enveloped viruses. Indeed, those target various stages of the life cycle in the viruses, and preferentially they interact with aromatic amino acids, either directly focusing on proteins of the virus or virus-associated host factors [20]. Moreover, in vivo studies have revealed that they inhibit low-pH conformational changes in the hemagglutinin (HA) and block the fusion process [58]. An in silico study revealed that a photoactive compound such as genistein, an isoflavone, which acts as phytoestrogen derived from soybeans is not only an anticancer but also is a potent inhibitor of main protease (Mpro, also termed as, 3Clpro) and RNA-dependent RNA polymerase (RdRp), which is required to synthesizes RNA out of the viral RNA template of SARS-CoV 2 [21] (Fig. 3).

\section{Inhibitors of Abl Kinase}

The enzyme Abl kinase acts as a scaffold protein in signaling pathways and regulates protein function with phosphorylation of downstream targets. Therefore, this enzyme can be used to block the virus-host fusion, as its activity is required by the virus to enter a host cell (Fig. 3). As a signal transduction inhibitor and protein-tyrosine kinase inhibitor, the drug imatinib mesylate is used as a targeted therapy, for cancer treatment, which too has been shown to oppose the entry of SARS-CoV-2 in vitro. Since, SARS-CoV2 prerequisites the action of $\mathrm{Abl}$ kinase to fuse and enter into the host cell, a low micromolar concentration with less toxicity could be used [59]. Furthermore, another drug, saracatinib, originally used to treat tuberous sclerosis complex (TSC) of lungs is a persuasive blocker of SARS-CoV-2 in initial screening assays [60].

\section{Inhibitors of ACE2}

ACE inhibitors prohibit SARS-CoV-2 fusion with the host cell (Fig. 3), although those also play a role in the spreading of lung fibrosis linked to COVID-19 infection. The SARS-CoV-2 spike protein uses ACE2 as a receptor to bind the host cell, therefore. If captopril and lisinopril (both being ACE2 inhibitors) are administrated by nebulization, the effect can be maximized on the lungs with lesser side effects [61]. This should be kept in mind that these may spread the lung fibrosis, as those also cause an increase of ACE2 levels in the host cell, especially in diabetes and/ or hypertension patients [62]. Among orally bioavailable drugs, ifenprodil hemitartrate, only an N-methyl-D-aspartate (NMDA) receptor competitor is a potential sigma $(\sigma)$ receptor agonist. If it is administrated orally, it seems to reduce the incursion of T-cells and neutrophils into the lungs and to eschew the liberation of proinflammatory cytokines. Thus, this can lead to the diminution of the lung inflammatory responses, lung fibrosis, and the vehemence of cough [63]. Therefore, ifenprodil hemitartrate could be a potential anti-COVID-19 drug.

\section{Regulators of Endosomal pH}

For the virus-host fusion through endocytosis and replication processes, the virus requires an acidic $\mathrm{pH}$ in the endosomal vesicles. Therefore, any compound that thwarts with endosome-mediated virus entry may hinder viral replication. Hydroxychloroquine and chloroquine both have efficiency as anti-COVID-19 medicines, by preventing the virus entry into the host cells (Fig. 3). However, the clinical efficacies of these medicines have not been portrayed, and those have a considerable amount of side effects [22, 64]; that is the reason for their disapproval by WHO in COVID-19 treatment [65]. 


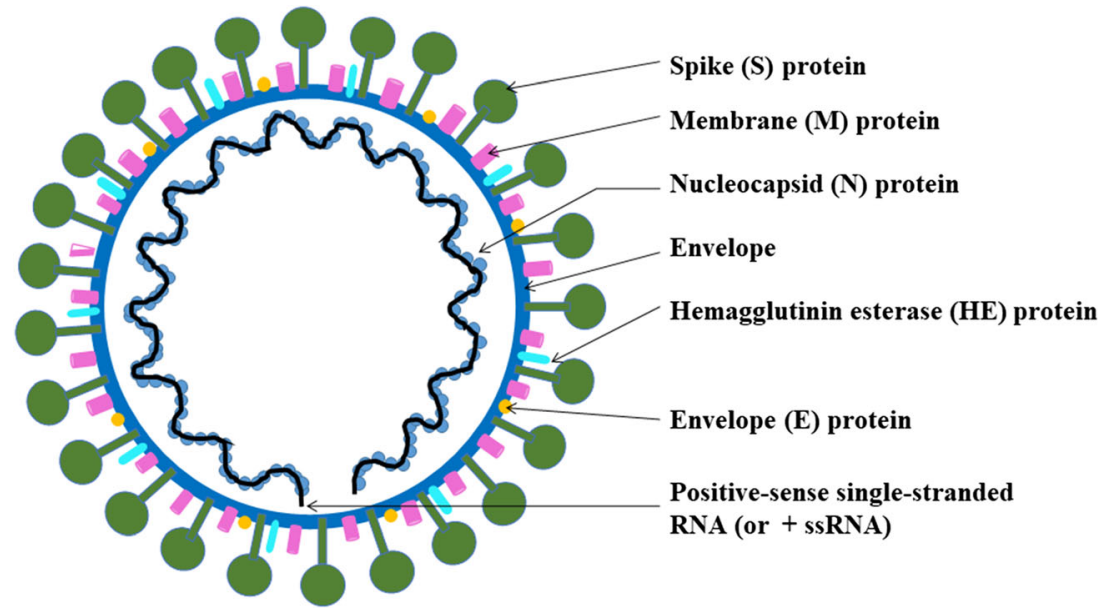

Fig. 1. Illustrative structure of SARS-CoV-2

Extracellular

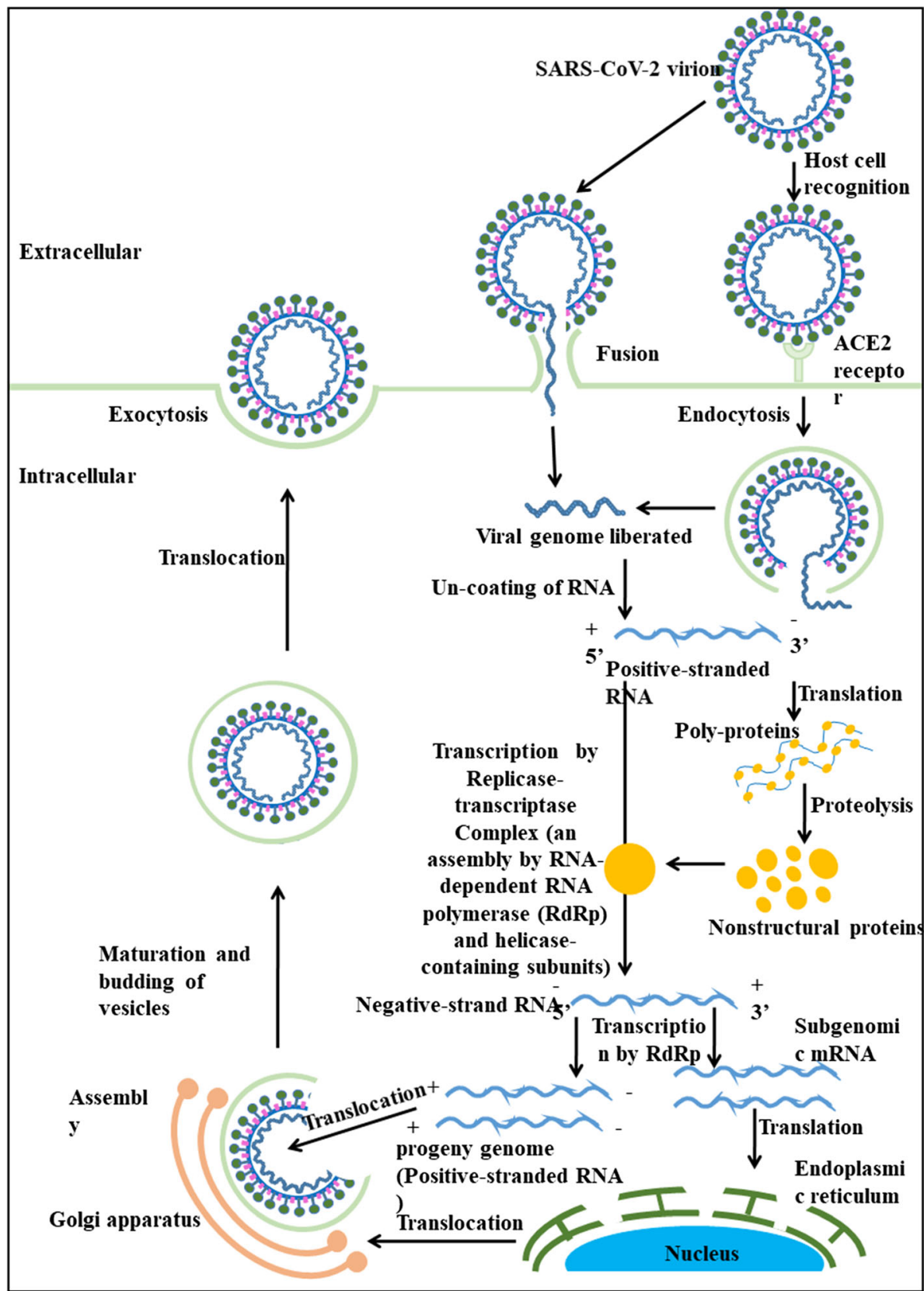

Fig. 2. Life cycle of SARS-CoV-2 


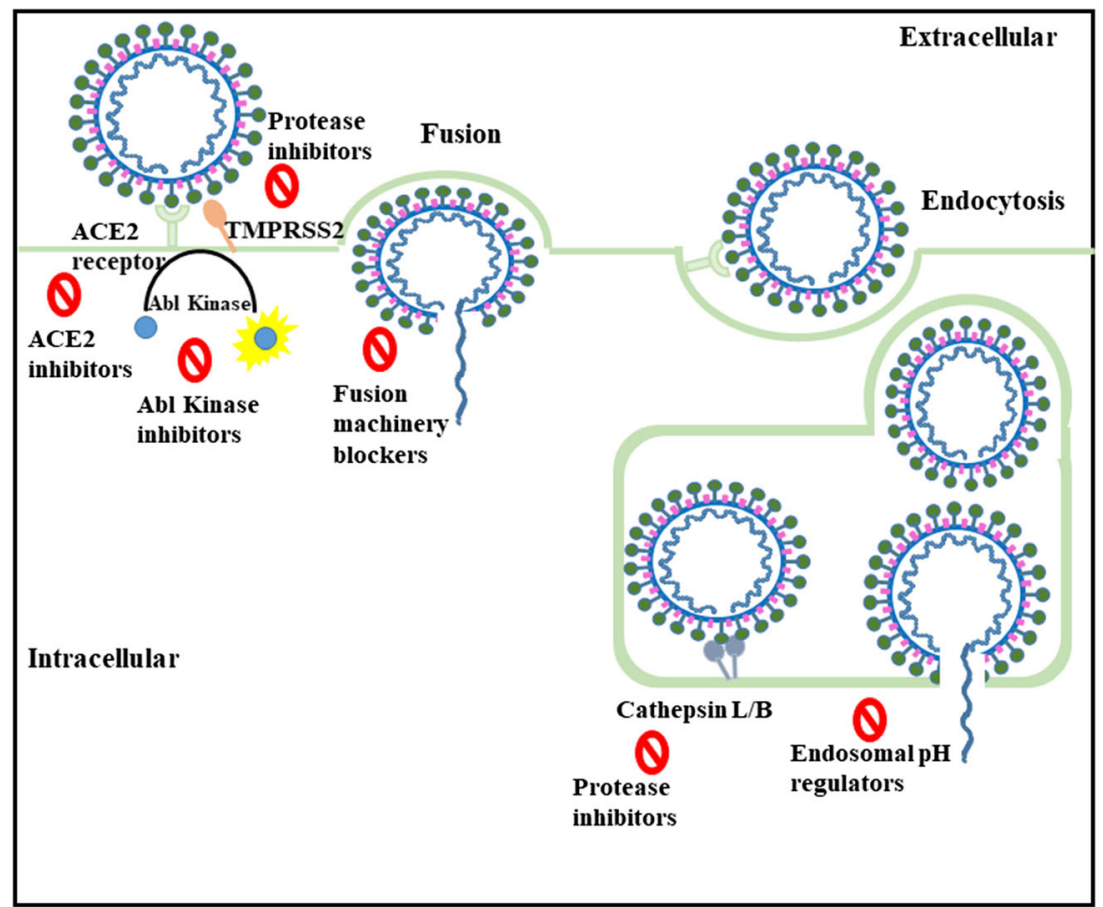

Fig. 3. Inhibitors of virus-host fusion

\section{TARGETING VIRUS REPLICATION}

\section{Inhibitors of Viral Protease}

The main protease (Mpro or 3C-like protease) and the papain-like protease (PLpro) handle the liberation of viral genomic RNA into the host cytoplasm. Therefore, blocking these proteases should impede the viral life cycle by avoiding proteolytic cleavage (Fig. 4), in a targeted manner, which is crucial for making the replicase complex ready for replication. Molecular docking and virtual screening studies had shown that the approved drugs for hepatitis $\mathrm{C}$ viral infection treatment, such as telaprevir, velpatasvir, grazoprevir, paritaprevir, and simeprevir had been recognized as potent drugs against SARS CoV2 [23, 66]. In silico studies have shown that the drug, asunaprevir, binds to more than 2 protein structures in SARS-CoV-2, impeding the virus growth [24]. FRET-based enzymatic assays had revealed that boceprevir is potent in targeting Mpro to inhibit viral replication [25], and it is now approved by the FDA [26].

Moreover, among the approved HIV protease inhibitors, some drugs shave shown potency against SARS-CoV-2 and some, for instance, darunavir, lopinavir, and ritonavir, are discontinued from COVID-19 treatment owing to insufficient evidence of efficacy $[65,67]$. Nelfinavir mesylate and saquinavir mesylate, both being anti-HIV protease inhibitor, are found to be replication blockers of SARS-CoV-2. Those were also found to show several cytopathic effects in cell culture, such as triggering apoptosis and necrosis along with cell protective mechanisms, particularly concerning cell cycle delaying and the unfolded protein responses [27-29].

Influenza neuraminidase inhibitors such as oseltamivir impede the dissemination of the influenza virus in patients $[30,31]$. When administered to COVID-19 patients, it had no positive outcome. However, when a combination of oseltamivir and other drugs was used, it improves the outcome [32, 33]. Peramivir, an influenza neuraminidase inhibitor, was found to be ineffective and is not advised now for the medication of COVID-19 [34, 68].

\section{Inhibitors of Oxysterol-Binding Protein}

The membrane-bound viral replication organelles (ER replication organelle membrane contact site) that form at the juxtaposition of membranes, amidst the ER and Golgi apparatus, are produced with the help of the oxysterolbinding protein (OSBP); therefore, OSBP inhibitors would impede the viral replication (Fig. 4). Itraconazole (ICZ), an antifungal used to treat histoplasmosis, a type of lung infection, is known to have antiviral activity against enterovirus. Further studies have revealed that it is a powerful broad-spectrum antiviral medicine for Picornaviridae and enveloped viruses such as the influenza A virus [35, 36, 69]. Another natural compound, OSW-1 [3 beta, 16 beta, 17 alpha-trihydroxycholest-5-en-22-one 16-O-(2-O-4methoxybenzoyl-beta-D-xylopyranosyl)-(1-> 3)-(2-O-acetylalpha-L-arabinopyranoside)], being a potent anticancer drug, is reported to inhibit OSBP in enterovirus and is assumed to be effective for SARS-CoV-2 [37, 38].

\section{Blockers of Viral Polymerase}

Since for transcription and replication, viruses encode their polymerases, nucleotide analogs are created as antiviral to baffle polymerase activity and to hinder the viral replication in infected cells (Fig. 4). Since the SARS-CoV-2 genome is ribosome-friendly, i.e., it has (+) ssRNA, it can make copies of its RNA once it finds and locks onto a ribosome. Its genome also carries a code for RNA-dependent RNA polymerase (RdRP), which, once attached to a ribosome, 


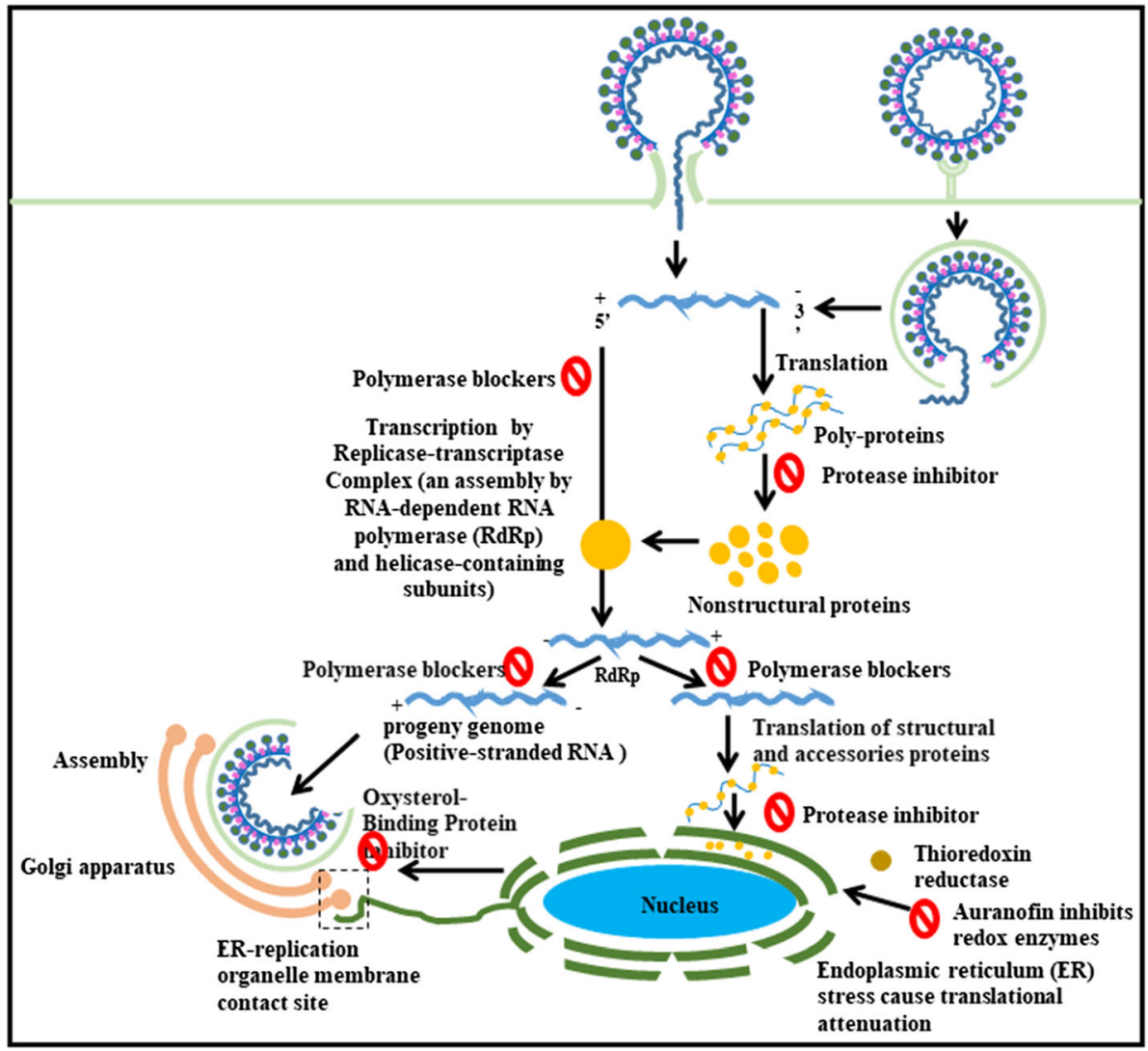

Fig. 4. Inhibitors of virus replication

can translate the viral polymerase. Remdesivir, an adenosine nucleoside analog primarily formulated to address the Ebola virus, has been testified as a broad-spectrum anti-RdRP agent, and it indicates some potency against COVID-19 treatment during clinical trials [7]. Remdesivir (which has a competitively inhibitory effect on nucleotide uptake by the virus) in combination with merimepodib (an inhibitor of the enzyme inosine monophosphate dehydrogenase (IMDPH), which is crucial for the synthesis of viral RNA as it has a crucial role in the synthesis of guanine nucleotide), is now being used during phase 2 clinical trials [39]. However, the newer literature suggested that its use had shown a little effect in hospitalized patients [9, 10]. In August 2020, the Journal of the American Medical Association (JAMA) promulgated about the clinical efficacy of remdesivir in phase 3 trials with standard care for moderate COVID-19 patients. They compared 10 days of treatment with remdesivir to that of placebo-controlled standard care and found out that there is no statistically significant difference with uncertain clinical importance for moderate COVID-19 patients. Remdesivir was indicated to be beneficial in a placebo-controlled trial for severe COVID-19 patients, but in moderate COVID-19 patients, its clinical efficacy is concealed $[9,10]$. Other similar nucleotide analogue drugs include ganciclovir/valganciclovir, entecavir, stavudine, abacavir, cidofovir, tenofovir, galidesivir, sofosbuvir, favipiravir, and ribavirin, which are approved by FDA for treating other viral infections [15, 16, 40]. Since safety profiles of these drugs are firmly established and those have shown a potent efficacy against SARS-CoV-2 in vitro, these could be assessed as clinical trials for COVID-19.

\section{Intracellular Redox Homeostasis}

Auranofin, a gold-thiol compound, which is used in the management of rheumatoid arthritis, has been shown to diminish SARS-CoV-2 replication in vitro. Moreover, auranofin inhibits redox enzymes, for example, the thioredoxin reductase induces ER stress and subsequently activates the unfolding of proteins (Fig. 4) [17, 18]. The ER stress elicits translational attenuation, cellular oxidative stress, and intrinsic apoptosis increase due to inhibition of these redox enzymes. Moreover, there is a reduction of cytokine production and stimulation of cell-mediated immunity as auranofin has anti-inflammatory properties [19].

\section{TARGETING HOST IMMUNE RESPONSES}

Thalidomide has been proven to prevent lung injury in H1N1 influenza virus infection by lowering nuclear factor kappa beta activity, reducing the concentration of chemokines (regulated upon activation, normal T-cell expressed and presumably secreted (RANTES) and interferon gamma-induced protein (IP) and cytokines (interleukin [IL]-6 and tumor necrosis factor $[\mathrm{TNF}]$ ), reducing infiltration of inflammatory cells, and improving survival rate [41]. The recent immune modulation studies [42, 43] have demonstrated that immune remodeling and immunomodulatory repercussions of thalidomide, which inhibits precarious cytokine storm and TNF in response to the lung injury associated with COVID-19 infection. In addition, thalidomide can also combat interstitial pulmonary fibrosis [70] indicating it to have potential therapeutic value for COVID-19 treatment. Some 
COVID-19 patients have reported an increase in IL-1 [71], which causes hyperinflammation. Anakinra, an IL-1 receptor antagonist authorized for rheumatoid arthritis, could be used for lowering hyperinflammation $[42,44]$ in COVID-19 patients.

\section{PROTEOMIC AND GENOMIC ANALYSES}

The proteomic and genomic analyses of SARS-CoV-2 have revealed that variations of its genome by deletion and insertion of nucleotides as typical part of evolution, since its recognition. These evolutionary changes have produced divergent viral proteins with modified amino acids. This clearly indicates that SARS-CoV-2 has been evolved molecularly from SARS coronavirus GD01 by a significant mutation in their translated proteins and the viral genes [72, 73].

These proteogenomic analyses suggest capricious sections primarily ORF10, spike, ORF9b, and ORF1ab genes should be exploited in molecular diagnosis of SARS-CoV-2 and can be the object against which specific antiviral drugs could be designed [72-74]. Quantitative and qualitative specification of proteomic and genomic mutations among the two variants of coronaviruses will not just empower engineering accurate drugs and strategize encountering the present viral strain but possibly somewhat enable us to generalize and prognosticate probable epidemics of newer strains during the upcoming years and thus be equipped in advance.

Analyses of the host proteome have revealed systematic discrepancies in levels of protein over the time of infection with SARS-CoV-2. There is a discrepancy in two principal agglomerates of proteins in the host cell post $24 \mathrm{~h}$ after infection of the virus. First, the group of cholesterol metabolism proteins increases, which degrade stored fats and synthesize functional and structural lipids such as those engaged in the fabrication of the cell wall. Second, RNA-modifying proteins increase, such as spliceosome components which remove introns from premessenger RNAs for ensuing translation by the ribosomes, after infection with SARS-CoV-2 [75, 76].

Experiments have shown the addition of spliceosome inhibitor such as pladienolide B, which aims for splicing factor SF3B1, to the human Caco-2 cells at nontoxic concentration, inhibits viral replication [77]. This also applies to cellular pathways such as carbon metabolism (i.e., glycolysis) where the addition of hexokinase inhibitors such as 2-deoxy-dglucose to the human Caco-2 cells at nontoxic concentration inhibits viral replication by glycolysis blockage and also alterations in proteins that are concerned for lipid metabolism $[78,79]$. Since coronavirus replication relies on the accessibility of the cell's nucleotide pools [80], evaluation of nucleic acid metabolism pathways showed similar results as above. The addition of a little of micromolar concentration of inosine monophosphate dehydrogenase inhibitors to the human Caco-2 cells, such as ribavirin, which inhibits de novo pathway of nucleotide synthesis of guanine base, inhibiting SARSCoV-2 replication $[76,81,82]$.

Together, these proteogenomic analyses divulged that SARS-CoV-2 remodels cellular pathways such as protein homeostasis (proteostasis), splicing, translation, carbon metabolism, and nucleic acid metabolism. This suggests those metabolism pathways are a potential therapeutic target for COVID-19 treatment as they are essential for SARS-CoV-2.

\section{CONCLUSION AND FUTURE PROSPECTIVE}

COVID-19 has occupied the present global scenario in public health, and its new strains have established a belligerent atmosphere everywhere in crowded countries. Until SARS-CoV-2 and its new strains have established the presently ongoing approved treatment and even after global vaccinations are completed, humanity should be prepared for attacks from the newer COVID-strains too. With limited time for drug testing and development, there is a huge urgency to the repurpose approved pharmaceutical drugs of well-known advantageous safety profiles to provide expeditious antiviral approaches for COVID-19 mutant variants or the newer strains. Above all, viral infections are arduous to cure due to the inherent mutating nature of their genomes, as well as quick development of resistance to human immunological systems and the administered antivirals, for which those unseen particles pose a highly significant hazard to humanity, everywhere. Till date, only a couple of medicines have been formulated to efficaciously handle viral diseases. With several already approved antiviral drug options, a long-term treatment for this novel coronavirus mutated strains could be formulated now. Humanity must unite, ignite, and fight against the ghoulish SARS CoV2.

\section{ACKNOWLEDGEMENTS}

The authors are thankful to the Utkal University and Siksha O Anusandhan Deemed to be University, Bhubaneswar, Odisha, India.

\section{Availability of Data and Materials No}

\section{AUTHOR CONTRIBUTION}

All authors have contributed significantly to the writing of this manuscript and critical revisions. Consequently, SSM and CRS drafted the figures and tables; RNP edited the whole manuscript. All authors read and approved the final manuscript.

\section{DECLARATIONS}

Ethics Approval and Consent to Participate Not applicable

Consent for Publication Not applicable

Competing Interests The authors declare no competing interests.

\section{REFERENCES}

1. Murthy S, Gomersall CD, Fowler RA. Care for critically ill patients with COVID-19. J Am Med Assoc. 2020;323(15):1499_ 500. https://doi.org/10.1001/jama.2020.3633.

2. Bikdeli B, Madhavan MV, Jimenez D, Chuich T, Dreyfus I, Driggin E, et al. COVID-19 and thrombotic or thromboembolic 
disease: implications for prevention, antithrombotic therapy, and follow-up: JACC state-of-the-art review. J Am Coll Cardiol. 2020;75(23):2950-73. https://doi.org/10.1016/j.jacc.2020.04.031.

3. Ye Q, Wang B, Mao J. The pathogenesis and treatment of the cytokine storm in COVID-19. J Inf Secur. 2020;80(6):607-13. https://doi.org/10.1016/j.jinf.2020.03.037.

4. Worldometer. Coronavirus update (live): cases and deaths from COVID-19 virus pandemic. Worldometers. 2021. Available from: https://www.worldometers.info/coronavirus

5. Organization WH. WHO timeline COVID-19. Who. 2020; Available from: https://www.who.int/news/item/27-04-2020-whotimeline \%2D\%2D-covid-19\%0Ahttps://www.who.int/news/ item/27-04-2020-who-timeline\%2D\%2D-covid-19\%0Ahttps:// www.who.int/news-room/detail/27-04-2020-whotimeline \%2D\%2D-covid-19

6. Wang Y, Zhang D, Du G, Du R, Zhao J, Jin Y, et al. Remdesivir in adults with severe COVID-19: a randomised, double-blind, placebo-controlled, multicentre trial. Lancet. 2020;395:1569-78. https://doi.org/10.1016/S0140-6736(20)31022-9.

7. Grein J, Ohmagari N, Shin D, Diaz G, Asperges E, Castagna A, et al. Compassionate use of remdesivir for patients with severe covid-19. N Engl J Med. 2020;382:2327-36. https://doi.org/ 10.1056/NEJMoa2007016.

8. Thanh Le T, Andreadakis Z, Kumar A, Gómez Román R, Tollefsen S, Saville M, et al. The COVID-19 vaccine development landscape. Nat Rev Drug Discov. 2020;19(5):305-6.

9. McCreary EK, Angus DC. Efficacy of Remdesivir in COVID19. J Am Med Assoc. 2020;324(11):1041-2. https://doi.org/ 10.1001/jama.2020.16337.

10. Spinner CD, Gottlieb RL, Criner GJ, Arribas López JR, Cattelan AM, Soriano Viladomiu A, et al. Effect of remdesivir vs standard care on clinical status at 11 days in patients with moderate COVID-19: a randomized clinical trial. J Am Med Assoc. 2020;324:1048-57. https://doi.org/10.1001/ jama.2020.16349.

11. Sanjuán R, Domingo-Calap P. Mechanisms of viral mutation. Cell Mol Life Sci. 2016;73(23):4433-48. https://doi.org/10.1007/ s00018-016-2299-6.

12. Peck KM, Lauring AS. Complexities of viral mutation rates. J Virol. 2018;92(14):e01031-17. https://doi.org/10.1128/JVI.0103117.

13. Duffy S. Why are RNA virus mutation rates so damn high? PLoS Biol. 2018;16(8):e3000003. https://doi.org/10.1371/ journal.pbio.3000003.

14. Uno Y. Camostat mesilate therapy for COVID-19. Intern Emerg Med. 2020;15(8):1577-8. https://doi.org/10.1007/s11739020-02345-9.

15. Elfiky AA. Ribavirin, remdesivir, sofosbuvir, galidesivir, and tenofovir against SARS-CoV-2 RNA dependent RNA polymerase (RdRp): a molecular docking study. Life Sci. 2020;253:117592. https://doi.org/10.1016/j.lfs.2020.117592.

16. Cai Q, Yang M, Liu D, Chen J, Shu D, Xia J, et al. Experimental treatment with favipiravir for COVID-19: an open-label control study engineering. 2020;6:1192-8. https:// doi.org/10.1016/j.eng.2020.03.007.

17. Wiederhold NP, Patterson TF, Srinivasan A, Chaturvedi AK, Fothergill AW, Wormley FL, et al. Repurposing auranofin as an antifungal: In vitro activity against a variety of medically important fungi. Virulence. 2017;8:138-42. https://doi.org/ 10.1080/21505594.2016.1196301.

18. May HC, Yu JJN, Guentzel M, Chambers JP, Cap AP, Arulanandam BP. Repurposing auranofin, ebselen, and PX-12 as antimicrobial agents targeting the thioredoxin system. Front Microbiol. 2018;9:336. https://doi.org/10.3389/fmicb.2018.00336.

19. Rothan HA, Stone S, Natekar J, Kumari P, Arora K, Kumar M. The FDA-approved gold drug auranofin inhibits novel coronavirus (SARS-COV-2) replication and attenuates inflammation in human cells. Virology. 2020;547:7-11. https://doi.org/10.1016/ j.virol.2020.05.002.

20. Wang X, Cao R, Zhang H, Liu J, Xu M, Hu H, et al. The antiinfluenza virus drug, arbidol is an efficient inhibitor of SARSCoV-2 in vitro. Cell Discov. 2020;6(1):1-5. https://doi.org/ 10.1038/s41421-020-0169-8.

21. Pendyala B, Patras A. In silico screening of food bioactive compounds to predict potential inhibitors of COVID-19 main protease (mpro) and RNA-dependent RNA polymerase (RdRp). ChemRxiv. 2020. https://doi.org/10.26434/ chemrxiv.12051927.v2.

22. Devaux CA, Rolain JM, Colson P, Raoult D. New insights on the antiviral effects of chloroquine against coronavirus: what to expect for COVID-19? Int J Antimicrob Agents. $2020 ; 55(5): 105938$. https://doi.org/10.1016/ j.ijantimicag.2020.105938.

23. Kouznetsova VL, Huang D, Tsigelny IF. Potential COVID-19 protease inhibitors: repurposing FDA approved drugs. ChemRxiv. 2020. https://doi.org/10.26434/chemrxiv.12093900.v1.

24. Shah B, Modi P, Sagar SR. In silico studies on therapeutic agents for COVID-19: drug repurposing approach. Life Sci. 2020;252:117652. https://doi.org/10.1016/j.lfs.2020.117652.

25. Ma C, Sacco MD, Hurst B, Townsend JA, Hu Y, Szeto T, et al. Boceprevir, GC-376, and calpain inhibitors II, XII inhibit SARS-CoV-2 viral replication by targeting the viral main protease. Cell Res. 2020;30:678-92. https://doi.org/10.1038/ s41422-020-0356-z.

26. Dai W, Zhang B, Jiang XM, Su H, Li J, Zhao Y, et al. Structurebased design of antiviral drug candidates targeting the SARSCoV-2 main protease. Science (80- ). 2020;368:1331-5. https:// doi.org/10.1126/science.abb4489.

27. Yamamoto N, Yang R, Yoshinaka Y, Amari S, Nakano T, Cinatl J, et al. HIV protease inhibitor nelfinavir inhibits replication of SARS-associated coronavirus. Biochem Biophys Res Commun. 2004;318:719-25. https://doi.org/10.1016/j.bbrc.2004.04.083.

28. Musarrat F, Chouljenko V, Dahal A, Nabi R, Chouljenko T, Jois $\mathrm{SD}$, et al. The anti-HIV drug nelfinavir mesylate (Viracept) is a potent inhibitor of cell fusion caused by the SARSCoV-2 spike (S) glycoprotein warranting further evaluation as an antiviral against COVID-19 infections. J Med Virol. 2020;92:2087-95. https://doi.org/10.1002/jmv.25985.

29. Mirzaei M, Harismah K, Da'I M, Salarrezaei E, Roshandel Z. Screening efficacy of available HIV protease inhibitors on COVID-19 protease. J Mil Med. 2020;22:100-7. https://doi.org/ 10.30491/JMM.22.2.100.

30. Whitley RJ, Hayden FG, Reisinger KS, Young N, Dutkowski R, Ipe $\mathrm{D}$, et al. Oral oseltamivir treatment of influenza in children. Pediatr Infect Dis J. 2001;20:127-33.

31. Li H, Wang YM, Xu JY, Cao B. [Potential antiviral therapeutics for 2019 novel coronavirus]. Zhonghua Jie $\mathrm{He} \mathrm{He} \mathrm{Hu} \mathrm{Xi} \mathrm{Za}$ Zhi. 2020;43:170-2. Available from: http:// www.ncbi.nlm.nih.gov/pubmed/32164080.

32. Wu R, Wang L, Kuo HCD, Shannar A, Peter R, Chou PJ, et al. An update on current therapeutic drugs treating COVID-19. Curr Pharmacol Reports. 2020;6(3):56-70. https://doi.org/ 10.1007/s40495-020-00216-7.

33. Chiba S. Effect of early oseltamivir on outpatients without hypoxia with suspected COVID-19. Wien Klin Wochenschr. 2020;133(7):292-7. https://doi.org/10.1007/s00508-020-01780-0.

34. Zhang L, Liu Y. Potential interventions for novel coronavirus in China: a systematic review. J Med Virol. 2020;92(5):479-90. https://doi.org/10.1002/jmv.25707.

35. Schloer S, Goretzko J, Kühnl A, Brunotte L, Ludwig S, Rescher $\mathrm{U}$. The clinically licensed antifungal drug itraconazole inhibits influenza virus in vitro and in vivo. Emerg Microbes Infect. 2019;8:80-93. https://doi.org/10.1080/22221751.2018.1559709.

36. Al-Khikani FHO, Hameed RM. COVID-19 treatment: possible role of itraconazole as new therapeutic option. (Special issue: COVID-19: supporting scientific surge.). Int J Heal Allied Sci. 2020;9:101-3 Available from: http://www.ijhas.in/ article.asp issn $=2278-344 \mathrm{X} \%$ 0 Ayear $=2020 \% 0$ Avolume $=$ $9 \%$ 0Aissue $=5 \%$ 0Aspage $=101 \%$ 0Aepage $=103$.

37. Albulescu L, Strating JRPM, Thibaut HJ, Van Der Linden L, Shair MD, Neyts J, et al. Broad-range inhibition of enterovirus replication by OSW-1, a natural compound targeting OSBP. Antivir Res. 2015;117:110-4. https://doi.org/10.1016/ j.antiviral.2015.02.013.

38. Roberts BL, Severance ZC, Bensen RC, Le-McClain AT, Malinky CA, Mettenbrink EM, et al. Differing activities of oxysterol-binding protein (OSBP) targeting anti-viral compounds. Antivir Res. 2019;170:104548. https://doi.org/10.1016/ j.antiviral.2019.104548. 
39. NCT04410354. Study of merimepodib in combination with remdesivir in adult patients with advanced COVID-19. A Phase 2, Randomized, Double-Blind, Placebo-Controlled Study Effic Saf Oral Merimepodib Comb With Intraven Remdesivir Adult Patients With Adv Coronavirus Dis 2019 [Internet]. 2020; Available from: http://ovidsp.ovid.com/ ovidweb.cgi? $\mathrm{T}=\mathrm{JS} \& \mathrm{PAGE}=$ reference $\& \mathrm{D}=$ cctr $\& \mathrm{NEWS}=\mathrm{N} \& \mathrm{~A}-$ $\mathrm{N}=\mathrm{CN}-02125067$

40. Jockusch S, Tao C, Li X, Anderson TK, Chien M, Kumar S, et al. A library of nucleotide analogues terminate RNA synthesis catalyzed by polymerases of coronaviruses that cause SARS and COVID-19. Antivir Res. 2020;180:104857. https:// doi.org/10.1016/j.antiviral.2020.104857.

41. Zhu H, Shi X, Ju D, Huang H, Wei W, Dong X. Antiinflammatory effect of thalidomide on H1N1 influenza virusinduced pulmonary injury in mice. Inflammation. 2014;37(6):2091-8. https://doi.org/10.1007/s10753-014-9943-9.

42. Zhong J, Tang J, Ye C, Dong L. The immunology of COVID19: is immune modulation an option for treatment? Lancet Rheumatol. 2020;2(7):e428-36. https://doi.org/10.1016/S26659913(20)30120-X.

43. Felsenstein S, Herbert JA, McNamara PS, Hedrich CM. COVID-19: immunology and treatment options. Clin Immunol. 2020;215:108448. https://doi.org/10.1016/j.clim.2020.108448.

44. Mehta P, McAuley DF, Brown M, Sanchez E, Tattersall RS, Manson JJ, et al. COVID-19: consider cytokine storm syndromes and immunosuppression. Lancet. 2020;395(10229):10334. https://doi.org/10.1016/S0140-6736(20)30628-0.

45. Naqvi AAT, Fatima K, Mohammad T, Fatima U, Singh IK, Singh A, et al. Insights into SARS-CoV-2 genome, structure, evolution, pathogenesis and therapies: structural genomics approach. Biochim Biophys Acta Mol basis Dis. 2020;13:165878. https://doi.org/10.1016/j.bbadis.2020.165878.

46. Weiss SR, Navas-Martin S. Coronavirus pathogenesis and the emerging pathogen severe acute respiratory syndrome coronavirus. Microbiol Mol Biol Rev. 2005;69:635-64. https://doi.org/ 10.1128/MMBR.69.4.635-664.2005.

47. Fehr AR, Perlman S. Coronaviruses: an overview of their replication and pathogenesis. Coronaviruses Methods Protoc. 2015:1-23. https://doi.org/10.1007/978-1-4939-2438-7_1.

48. Shereen MA, Khan S, Kazmi A, Bashir N, Siddique R. COVID19 infection: origin, transmission, and characteristics of human coronaviruses. J Adv Res. 2020;24:91-8. https://doi.org/10.1016/ j.jare.2020.03.005.

49. Mousavizadeh L, Ghasemi S. Genotype and phenotype of COVID-19: their roles in pathogenesis. J Microbiol Immunol Infect. 2020;54:159-63. https://doi.org/10.1016/j.jmii.2020.03.022.

50. Li X, Geng M, Peng Y, Meng L, Lu S. Molecular immune pathogenesis and diagnosis of COVID-19. J Pharm Anal. 2020;10(2):102-8. https://doi.org/10.1016/j.jpha.2020.03.001.

51. Perlman S, Netland J. Coronaviruses post-SARS: update on replication and pathogenesis. Nat Rev Microbiol. 2009;7(6):43950. https://doi.org/10.1038/nrmicro2147.

52. Nagy PD, Pogany J. The dependence of viral RNA replication on co-opted host factors. Nat Rev Microbiol. 2012;10(2):137-49. https://doi.org/10.1038/nrmicro2692.

53. Bittmann S. COVID 19: camostat and the role of serine protease entry inhibitor TMPRSS2. J Regen Biol Med. 2020;2(2):1-2. https://doi.org/10.37191/Mapsci-2582-385X-2(2)020.

54. US National Library of Medicine. Camostat mesylate in COVID-19 outpatients, ClinicalTrials.Gov. ClinicalTrials. 2020; Available from: https://clinicaltrials.gov/ct2/show/NCT04353284.

55. Padmanabhan P, Desikan R, Dixit NM. Targeting TMPRSS2 and cathepsin $\mathrm{B} / \mathrm{L}$ together may be synergistic against SARSCoV-2 infection. PLoS Comput Biol. 2020;16(12):e1008461. https://doi.org/10.1371/journal.pcbi.1008461.

56. Tang T, Bidon M, Jaimes JA, Whittaker GR, Daniel S. Coronavirus membrane fusion mechanism offers a potential target for antiviral development. Antivir Res. 2020;178:104792. https://doi.org/10.1016/j.antiviral.2020.104792.

57. McKee DL, Sternberg A, Stange U, Laufer S, Naujokat C. Candidate drugs against SARS-CoV-2 and COVID-19. Pharmacol Res. 2020;104859:104859. https://doi.org/10.1016/ j.phrs.2020.104859.
58. Kadam RU, Wilson IA. Structural basis of influenza virus fusion inhibition by the antiviral drug Arbidol. Proc Natl Acad Sci U S A. 2017;114:206-14.

59. Cao B, Wang Y, Wen D, Liu W, Wang J, Fan G, et al. A trial of lopinavir-ritonavir in adults hospitalized with severe Covid-19. N Engl J Med. 2020;382:1787-99. https://doi.org/10.1056/ NEJMoa2001282.

60. Flanagan C, Griffin R, Langreth R. Coronavirus vaccine tracker: race for a Covid-19 cure. Bloomberg. 2020.

61. Xu X, Han M, Li T, Sun W, Wang D, Fu B, et al. Effective treatment of severe COVID-19 patients with tocilizumab. Proc Natl Acad Sci U S A. 2020;117:10970-5.

62. Bialek S, Boundy E, Bowen V, Chow N, Cohn A, Dowling N, et al. Severe outcomes among patients with coronavirus disease 2019 (COVID-19) - United States, February 12-March 16, 2020. MMWR Morb Mortal Wkly Rep. 2020;69:343-6.

63. Nct. Safety and Efficacy of NP-120 (Ifenprodil) for the Treatment of confirmed COVID-19 infected hospitalized patients. https://clinicaltrials.gov/show/NCT04382924. 2020; Available from: https://www.cochranelibrary.com/central/doi/10.1002/ central/CN-02124518/full.

64. Sahoo CR, Paidesetty SK, Padhy RN. Newly developed semisynthetic chloroquine and hydroxychloroquine-phytochemical conjugates as prospective COVID-19 drug(s). ChemRxiv. 2020. https://doi.org/10.26434/chemrxiv.12198039.v1.

65. NCT04343677. Military COVID-19 Hydroxychloroquine preexposure and post-exposure prophylaxis study. Mil COVID-19 hydroxychloroquine pre-exposure post-exposure prophyl study. 2020.

66. Hosseini FS, Amanlou M. Anti-HCV and anti-malaria agent, potential candidates to repurpose for coronavirus infection: virtual screening, molecular docking, and molecular dynamics simulation study. Life Sci. 2020;258:118205. https://doi.org/ 10.1016/j.lfs.2020.118205.

67. Rawson TM, Moore LSP, Zhu N, Ranganathan N, Skolimowska $\mathrm{K}$, Gilchrist $\mathrm{M}$, et al. Bacterial and fungal coinfection in individuals with coronavirus: a rapid review to support COVID-19 antimicrobial prescribing. Clin Infect Dis. 2020;71:2459-68. https://doi.org/10.1093/cid/ciaa530.

68. Cao Y Chen, Deng Q xin, Dai S xue. Remdesivir for severe acute respiratory syndrome coronavirus 2 causing COVID-19: an evaluation of the evidence. Travel Med Infect Dis. 2020; 35:101647. https://doi.org/10.1016/j.tmaid.2020.101647.

69. Shim A, Song JH, Kwon BE, Lee JJ, Ahn JH, Kim YJ, et al. Therapeutic and prophylactic activity of itraconazole against human rhinovirus infection in a murine model. Sci Rep. 2016;6(1):1-12. https://doi.org/10.1038/srep23110(2016).

70. Haraf R, Flora AS, Assaly R. Thalidomide as a cough suppressant in idiopathic pulmonary Fibrosis. Am $\mathrm{J}$ Ther. 2018;25(6):e687-8. https://doi.org/10.1097/ MJT.0000000000000695.

71. Huang C, Wang Y, Li X, Ren L, Zhao J, Hu Y, et al. Clinical features of patients infected with 2019 novel coronavirus in Wuhan, China [published correction appears in Lancet]. Lancet. 2020;395(10223):497-506. https://doi.org/10.1016/S01406736(20)30183-5.

72. Wu F, Zhao S, Yu B, Chen YM, Wang W, Song ZG, et al. A new coronavirus associated with human respiratory disease in China. Nature. 2020;579:265-9. https://doi.org/10.1038/s41586-020-2008-3.

73. Hassanin AA, Mahgoub EI, Sitohy B, Sitohy M. Genomic and proteomic comparative analysis of SARS-CoV-2 versus SARSCoV-GD01. Research Square. 2020. In Press. https://doi.org/ 10.21203/rs.3.rs-32189/v1.

74. Tushir S, Kamanna S, Nath SS, Bhat A, Rose S, Aithal AR, et al. Proteo-genomic analysis of SARS-CoV-2: a clinical landscape of single-nucleotide polymorphisms, COVID-19 proteome, and host responses. J Proteome Res. 2021;20(3):1591601. https://doi.org/10.1021/acs.jproteome.0c00808.

75. Song T, Fang L, Wang D, Zhang R, Zeng S, An K, et al. Quantitative interactome reveals that porcine reproductive and respiratory syndrome virus nonstructural protein 2 forms a complex with viral nucleocapsid protein and cellular vimentin. J Proteome. 2016;142:70-81. https://doi.org/10.1016/ j.jprot.2016.05.009. 
76. Bojkova D, Klann K, Koch B, Widera M, Krause D, Ciesek S, et al. Proteomics of SARS-CoV-2-infected host cells reveals therapy targets. Nature. 2020;583(7816):469-72. https://doi.org/ 10.1038/s41586-020-2332-7.

77. Cretu C, Agrawal AA, Cook A, et al. Structural basis of splicing modulation by antitumor macrolide compounds. Mol Cell. 2018;70(2):265-273.e8. https://doi.org/10.1016/ j.molcell.2018.03.011.

78. Gualdoni GA, Mayer KA, Kapsch AM, Kreuzberg K, Puck A, Kienzl P, et al. Rhinovirus induces an anabolic reprogramming in host cell metabolism essential for viral replication. Proc Natl Acad Sci U S A. 2018;115(30):E7158-65. https://doi.org/10.1073/ pnas.1800525115.

79. Yan B, Chu H, Yang D, Sze KH, Lai PM, Yuan S, et al. Characterization Of the lipidomic profile of human coronavirusinfected cells: implications for lipid metabolism remodeling upon coronavirus replication. Viruses. 2019;11(1):73. https:// doi.org/10.3390/v11010073.
80. Pruijssers AJ, Denison MR. Nucleoside analogues for the treatment of coronavirus infections. Curr Opin Virol. 2019;35:57-62. https://doi.org/10.1016/j.coviro.2019.04.002.

81. Marcelin JR, Wilson JW. Razonable RR; Mayo Clinic Hematology/Oncology and Transplant Infectious Diseases Services. Oral ribavirin therapy for respiratory syncytial virus infections in moderately to severely immunocompromised patients. Transpl Infect Dis. 2014;16(2):242-50. https://doi.org/ 10.1111/tid.12194.

82. Wu LS, Rower JE, Burton JR Jr, Anderson PL, Hammond KP, Baouchi-Mokrane F, et al. Population pharmacokinetic modeling of plasma and intracellular ribavirin concentrations in patients with chronic hepatitis $\mathrm{C}$ virus infection. Antimicrob Agents Chemother. 2015;59(4):2179-88. https://doi.org/10.1128/ AAC.04618-14.

Publisher's Note Springer Nature remains neutral with regard to jurisdictional claims in published maps and institutional affiliations. 